\title{
COMPOSITION OF GAS BUBBLES IN GREENLAND IGEBERGS
}

By P. F. Scholander

(Zoophysiological Institute, University of Oslo, and Scripps Institution of Oceanography, University of California)

E. A. Hemmingsen

(Zoophysiological Institute, University of Oslo)*

L. K. Coachman

(Department of Oceanography, University of Washington)

and D. C. NutT

(Department of Geography, Dartmouth Gollege, Hanover, N.H.)

\begin{abstract}
An investigation has been made on the amounts and composition of gases enclosed in West Greenland glaciers ranging from the Thule area near lat. $77^{\circ} \mathrm{N}$. to Brede Fjord at lat. $62^{\circ} \mathrm{N}$. In general, the gas composition deviated appreciably from that of air, and also varied within each piece of ice. Presumably these variations are caused by melting either in the firn area, or, more often, at the outlet sites. ${ }^{13} \mathrm{C}$ analyses indicate that organic contamination of the snow may be another factor. Undisturbed ancient atmospheric air was therefore not encountered in our Greenland samples, but indications are that it might be found in the much colder Antarctic ice sheet. Gas bubbles analyzed from crack fills in icebergs had high oxygen concentrations, sometimes almost matching that of air-equilibrated ice-cold water, from which they undoubtedly originated. Blue icebergs, which often were seen floating up from the bottom of glacier fronts, also tended toward high oxygen concentration and very likely, therefore, are caused by freezing of melt water seeping down and collecting underneath the glacier.
\end{abstract}

RÉsumé. Des recherches pour déterminer la quantité et la composition des gaz occlus dans la glace ont été effectuées sur les glaciers de la côte ouest du Groenland entre la région de Thule $\left(77^{\circ} \mathrm{N}\right)$ et Bredefjord $\left(62^{\circ} \mathrm{N}\right)$. En général, la composition des gaz différait de beaucoup de celle de l'air, et de plus variait d'un échantillon à l'autre. Probablement, ces variations sont dues à la fonte à la fois dans la zone d'accumulation et plus souvent dans celle du dissipateur. Les analyses de ${ }^{13} \mathrm{C}$ montrent que les impuretés organiques de la neige peuvent en constituer un autre facteur. L'air originel n'a donc jamais été trouvé dans nos échantillons du Groenland, mais il semble que l'on puisse les trouver dans l'indlandsis antarctique plus froid. L'analyse des occlusions gazeuses de la glace de congélation remplissant les failles des icebergs met en évidence une forte concentration d'oxygène atteignant parfois celle de l'eau de fusion en équilibre avec l'air, origine de cette glace. Des iccbergs de glace bleue comme on en trouve décollant du fond et flottant devant le front des glaciers avaient aussi une forte concentration en oxygène ainsi causée par la congélation de l'cau de fonte qui s'infiltre dans la glace et se rassemble en poches sous-glaciaires.

Zusammenfassung. In Gletschern Westgrönlands zwischen Thule bei $77^{\circ}$ und Brede Fjord in $62^{\circ}$ nördl. Breite wurde die Menge und Zusammensetzung von eingeschlossenen Gasen untersucht. Im allgemeinen wich die Zusammensetzung merklich von der der Luft ab, sie variierte auch innerhalb jeden Eisstücks. Die Verschiedenheiten sind mutmasslich durch das Schmelzen im Firnbercich, noch öfter in den Aussenbereichen bedingt. ${ }^{13} \mathrm{C}$ Analysen zeigen an, dass organische Verunreinigung des Schnees eine weitere Ursache sein kann. Ungestörte alte Luft wurde deshalb in unseren grönländischen Proben nicht angetroffen, aber es sind Anzeichen vorhanden, dass ungestörte Luft in dem viel kälteren antarktischen Eisschild gefunden werden könnte. Analysen von Gasblasen aus Spaltenfüllungen in Eisbergen ergaben starke Sauerstoffkonzentrationen, die manchmal annährend dem ausgeglichenen Luftanteil von eiskaltem Wasser entsprechen, aus dem die Füllungen hervorgegangen sind. Blaue Eisberge, die man oft von dem Grund der Gletscherfronten auftauchen sicht, neigen auch zu starken Sauerstoffkonzentrationen; sie sind deshalb wahrscheinlich durch Gefrieren von Schmelzwasser entstanden, das in den Gletscher eingedrungen ist und sich am Gletscherboden gesammelt hat.

\section{INTRODUCTION}

Diffusion experiments on thin sheets of ice have shown that ice is extremely impervious to gases. The diffusion rate of carbon dioxide gas can, however, be measured, and increases rapidly when the temperature approaches $0^{\circ} \mathrm{C}$. But oxygen diffusion, in spite of the smaller molecules, so far has not proved measurable. There is no evidence that the ice lattice itself can dissolve gases, so it appears that what minute diffusion takes place occurs in intercrystalline liquid brine films. ${ }^{\mathbf{1}, 2}$

* Present address: Scripps Institution of Oceanography, University of California, La Jolla, California. 
When glacier ice is formed by compaction of snow on a high polar inland ice sheet, some 3 to 8 volumes per cent of air at ambient pressure is trapped between the ice crystals and incorporated as bubbles under pressure into the ice. The composition of these gas bubbles should therefore be exactly that of the atmosphere; and as long as the ice remained well below freezing, one would expect this air to be preserved for thousands of years, for compared to the diffusion rate, the distances in the glacier are enormous and so is the amount of gas trapped. The analysis of such gases from high polar glaciers might thus give information as to atmospheric composition at the time the ice was formed. 3.5

This simple condition is changed, however, if melting occurs, for when air dissolves in water, the components dissolve in proportions quite different from those present in the atmosphere. While oxygen composes $20 \cdot 9$ per cent of the air, it becomes $34 \cdot 9$ per cent when air dissolves in ice-cold water. Likewise argon and carbon dioxide, which are 0.9 per cent and 0.03 per cent in air respectively, become 1.9 per cent and $\mathrm{I} \cdot 8$ per cent of the air dissolved in water.

Therefore, if air-equilibrated melt water seeps down through the snow and freezes, the dissolved gases separate out and enrich any entrapped air in carbon dioxide, argon and oxygen. And conversely, if glacier ice with air bubbles melts, one would expect a differential loss of the more soluble components, for as soon as the ice becomes water-pervious, near $0^{\circ} \mathrm{C}$., the bubbles under pressure will expand, extruding their associated melt water with preferential loss of the more soluble components. 4,5 The considerable loss of oxygen and argon found as one descended the Norwegian glacier Storbreen confirmed this interpretation. ${ }^{6}$

It is reasonable, therefore, that one might only find undisturbed atmospheric air provided ice could be obtained that had never been subjected to melting or near-melting temperatures. This, again, means high polar source areas and protection against summer heating. Even then, one condition could upset it all, namely, if the snowflakes themselves contained measurable amounts of gas deviating from air composition. This could possibly happen if supercooled fog drops were suddenly to freeze on contact with snow or ice surfaces. Possibly the dissolved gases might then be incorporated as bubbles in the ice. However, when large snowflakes of a temperate climate were examined under cold kerosene, no gases could be detected trapped within them. Another possible source of contamination would be if atmospheric gases were adsorbed to the snow crystals in significant amounts.

An important aspect of the possibility of finding undisturbed atmospheric air preserved in glacier ice is that a rigorous check is always available, namely, that the gas composition over wide areas of the collecting site must be absolutely uniform. If it is not, it cannot be undisturbed air, and if it is uniform in both depth and area, it is overwhelmingly likely that we are dealing with old air, because any conceivable contamination would be patchy.

A quest for ancient atmosphere trapped and preserved in glacier ice became even more tempting when preliminary experiments on Storbreen in Norway demonstrated that it was technically feasible to date the ice by the ${ }^{\mathrm{I}} \mathrm{C}$ method using the carbon dioxide in its trapped air. 7 This required mining and vacuum extraction of about ro tons of ice in order to. yield one single dating sample of $0.2 \mathrm{~g}$. of carbon. The results showed that it took the ice some 700 years to pass through this small temperate glacier, and this opened the possibility for studying atmospheric composition also in time.

The great ice sheets of Antarctica and Greenland would offer the best sources of ice for our purpose, and for logistic reasons it was therefore planned to make a study of a number of the major outlet glaciers in West Greenland. Since the carbon dating procedure required extensive extraction equipment plus a laboratory and machine shop, shipboard operation was decided upon. With these facilities, several parameters of the gas enclosures could be studied, such as pressure, amount, composition and age, as well as the isotopic composition of the ice itself.

The present investigation was performed on the Arctic Institute Greenland Expedition 
1958. The expedition chartered a Norwegian seal hunter, the I I 4-ft. (35 m.) M/S Rundoy. The vessel was modified by adding a $12 \times 15 \mathrm{ft} .(3.6 \times 4.6 \mathrm{~m}$. $)$ deck laboratory, a lathe, and other shop facilities. The area of operation extended from Brede Fjord in the south to Melville Bugt in the north (Fig. I). This paper reports the results of analyses for gas quantity and composition. Results of investigations of other parameters are being reported elsewhere. 8,9 , 10

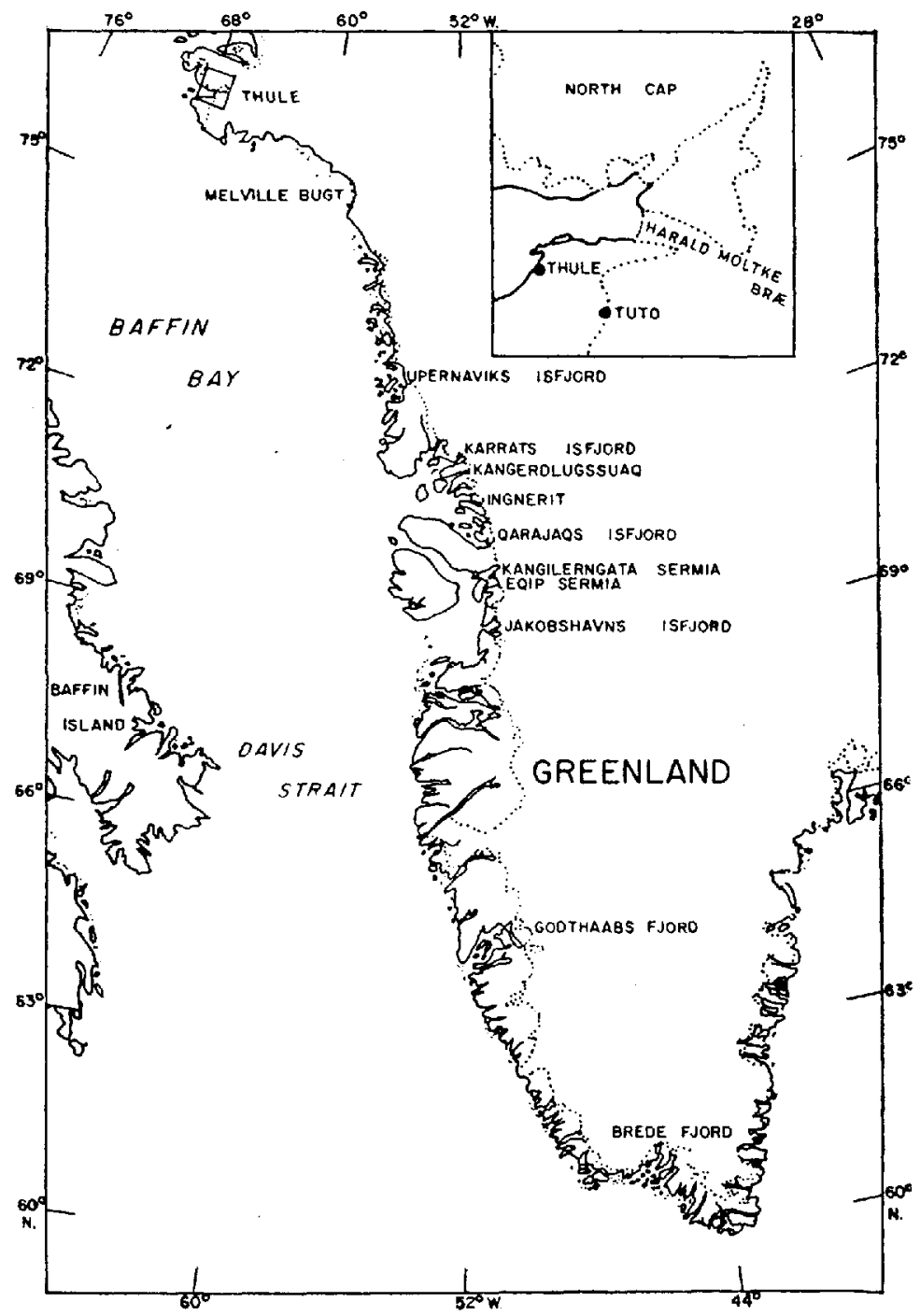

Fig. I. Sample locations on the Arctic Institute Greenland Expedition 1958

\section{Methods}

\section{Sampling of ice}

Most samples were taken from large pieces of ice dropping off the vertical sides of single icebergs, or from the glacier front itself. These pieces were retrieved by motor boat, towed to the ship, and split into ton-sized pieces by steam knife and wooden wedges, and hoisted on board. The surface layer was trimmed off before chipping off pieces for the extraction pots. 
In other cases where dating was not done, smaller pieces were used. When the dry shaving technique was used, 5 the pieces were stored in the freeze room of the ship in order to lower the temperature of the ice.

In a special series of samples obtained at Thule in 1956 , Coachman collected surface samples from various glaciers, flying to the site in a helicopter, and other samples were collected in two tunnels dug into the inland ice (Fig. 2). These samples, mostly several kilograms in weight, were transported at about $-10^{\circ} \mathrm{G}$. to Oslo. Checks showed that no significant change in gas composition took place during five months' further storage.

\section{Extraction of gas}

Examination of the gases enclosed in the ice involved three steps: (a) the extraction and measurement of the gas; (b) analysis of part of the sample for content of $\mathrm{CO}_{2}$, oxygen and nitrogen, performed on the ship; (c) storage of gas and water samples for later analyses of argon and isotopes at a base laboratory.

Three methods were used for extraction of the gas: (I) cold extraction of the ice by shaving it up with a rotary knife under vacuum; (2) boiling off the gases under vacuum; and (3) puncture and microanalysis of single or a few bubbles.

\section{(1) The cold extraction method}

The cold extraction method of Coachman and others 5 was used in the beginning, but was soon replaced by a vacuum melting technique which is more convenient and easily yields samples large enough for both analysis and storage.

\section{(2) Extraction of gas by vacuum boiling}

Ice $(2-3 \mathrm{~kg}$.) is placed in a 5 -liter enameled pot, which is closed vacuum tight with an $\mathrm{O}$-ring-sealed lid which carries a reflux condenser. The latter is connected with the vacuum extraction system and gas sampling device as seen in Figure 3. The air is now pumped out of the system, heat is applied, and the gases liberated by the melting and boiling are collected in the mercury extractor unit. The steam is held back by the reflux condenser. When all gas has been driven out of the pot, the condenser usually fills with water, whereupon this assembly is shut off and disconnected. The amount of gas yielded by the ice is measured in the extractor at one atmosphere's pressure, and part of it is let into the evacuated sampling tube at a pressure below ambient, so the tube may be easily sealed off by a torch. The other' end of the sampling tube carries a break-off tip inside its connecting tube. These tubes were stored and later analyzed for argon by means of mass spectrometry. The remainder of the gas is transferred to a gas pipette for analysis of $\mathrm{CO}_{2}$, oxygen and nitrogen in the $\frac{1}{2} \mathrm{~cm} .{ }^{3}$ analyzer. ${ }^{\text {II }} \mathrm{By}$ measuring the volume of melt water in the pot, the gas content in the ice can be calculated.

The accuracy of this technique was tested by introducing $300 \mathrm{~cm} .{ }^{3}$ of air into the cold gas-free water of the evacuated boiler. After 3 hours' equilibration, boiling was started and the gas was retrieved in the sampling device. The concentration found for $\mathrm{O}_{2}$ and $\mathrm{CO}_{2}$ was identical with that in air.

\section{(3) Micro-analysis of gas in single bubbles}

In certain cases it may be of interest to analyze the composition of single or a few bubbles. A well is then shaved above the bubble and filled with cold mercury. The thin ice shell separating the mercury from the bubble is pierced with a mercury-filled micro-syringe into which the gas is drawn, followed by mercury from the well. 1o to $20 \mathrm{~mm} .^{3}$ of this gas is analyzed in the water analyzer, ${ }^{\mathbf{1 2}}$ or in cases where less than a few $\mathrm{mm} \cdot{ }^{3}$ is available, the micro-method of Scholander and Evans ${ }^{13}$ has been used. ${ }^{5}$ 


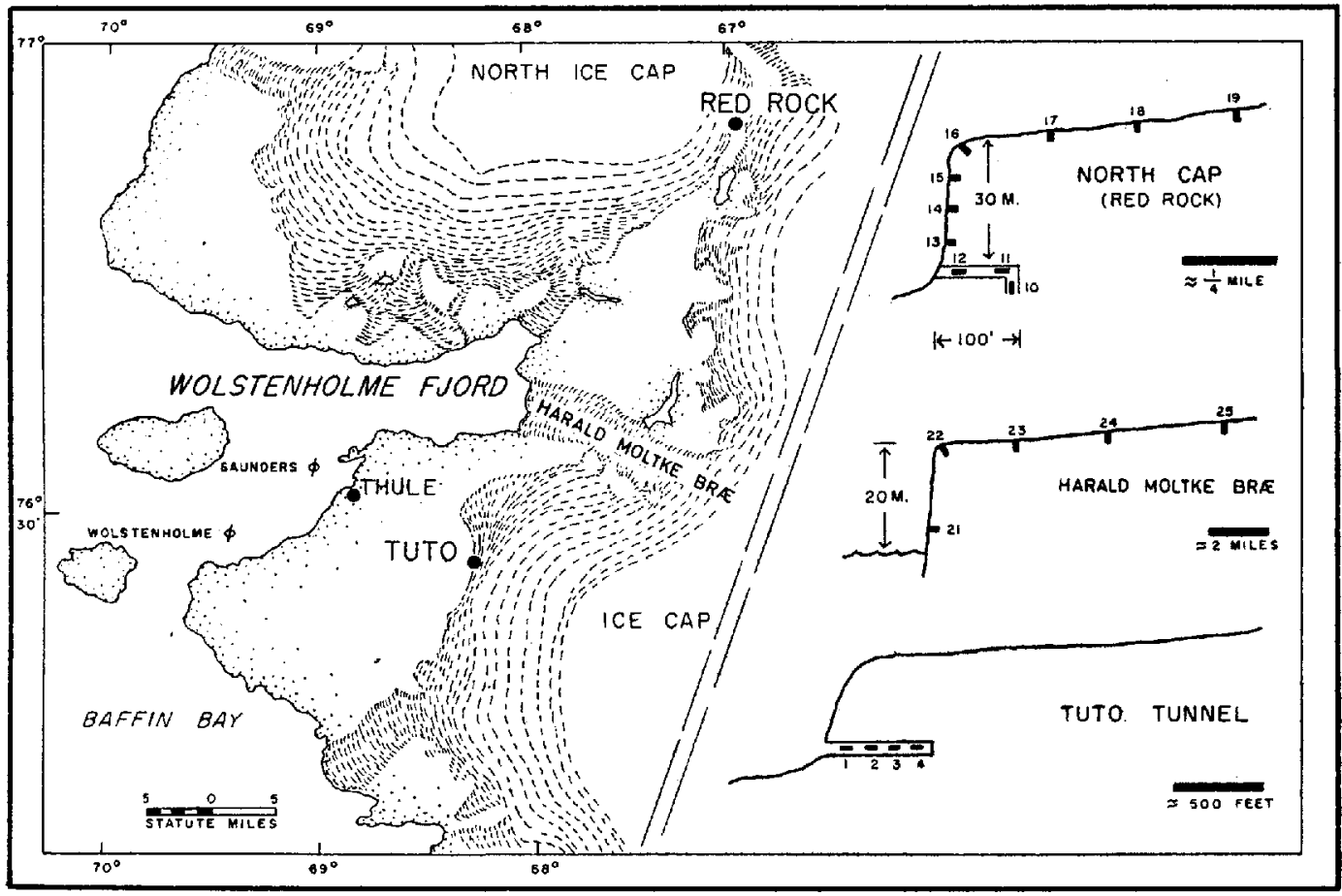

Fig. 2. Sample sites in the Thule area, 1956 :

a. Red Rock Cliff, small ice cap north of Thule

b. Harald Molike Bre, fast-moving glacier north-east of Thule, feeding from main ice sheet

c. Tuto Tunnel, a 550-ft. tunnel dug into the static edge of the main ice sheet south-east of Thule

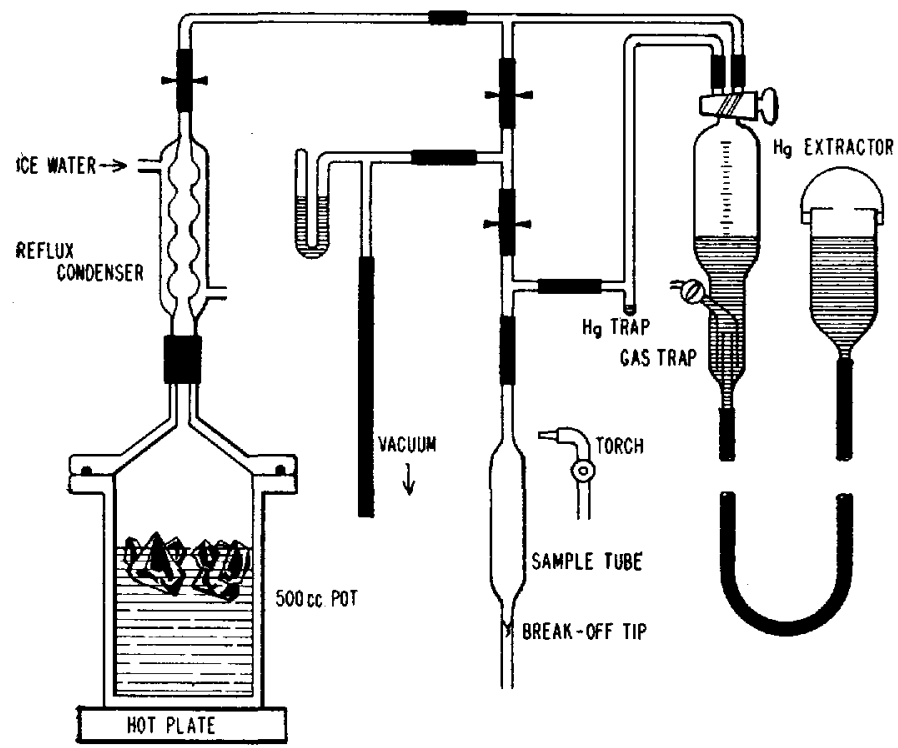

Fig. 3. Apparatus for quantitative extraction of gases in ice 


\section{Results}

\section{Volume of gas}

The volume of gas trapped in the ice and measured at one atmosphere's pressure was usually between 3 and $8 \mathrm{~cm} .{ }^{3}$ per $100 \mathrm{~cm} .{ }^{3}$ of ice, varying somewhat from berg to berg (Fig. 4). Some bergs might have from 3 to 5 volumes per cent gas, others 6 to 8 volumes per cent in the various samples taken, and other bergs in between. Neither in the Rundey data nor in the data obtained at Thule is there any apparent correlation between the amount of gas trapped and other parameters, such as composition or pressure.
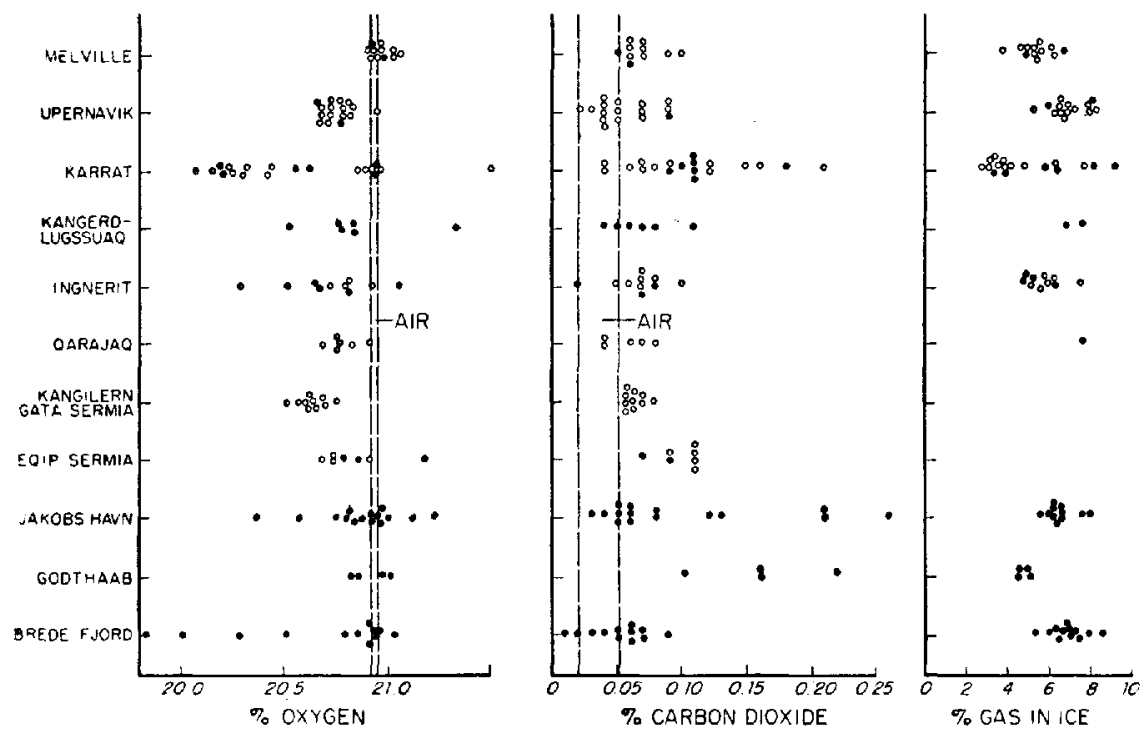

Fig. 4. Composition and quantity of gas in Greenland glacier ice

\section{Composition of the gas}

The composition of the gas bubbles will be seen from Figures 4 and 5 . In Figure 4 are given the data obtained on the Rundyy expedition from Melville Bugt to Brede Fjord. This represents an entirely random sampling with respect to glacier topography, and it will be seen that in every iceberg tested there are appreciable variations in the gas composition, even from adjacent pieces or the same piece of ice; that is, the original air bubbles have all been contaminated or altered. Most oxygen in this series is between $20 \cdot 20$ and $2 \mathrm{I} \cdot 00$ per cent; that is, generally lower than in air, whereas carbon dioxide is mostly higher than air, $0 \cdot 04$ to $0 \cdot 10$ per cent. Within this series, however, ${ }^{14} \mathrm{C}$ and ${ }^{18} \mathrm{O}$ determinations showed that ice of the greatest age and coldest origin (Upernavik and Kangilerngata Sermia) had relatively low variability in gas composition, i.e., 23 of 25 samples showed 0.04 to 0.09 per cent $\mathrm{CO}_{2}$ and $20 \cdot 60$ to $20 \cdot 80$ per cent oxygen. This suggests that a search for old undisturbed atmosphere might still pay off in glaciers of the coldest possible origin such as found on the Antarctic Ice Sheet.

Another series of determinations was taken at Thule, North Cap, the Harald Moltke Bræ, and the Tuto Tunnel (Fig. 2). The concentrations of oxygen, argon and carbon dioxide in these samples were mostly higher than in air, and varied greatly within each piece of ice (Fig. 5). There appeared to be no clear geographical or topographical correlation. 


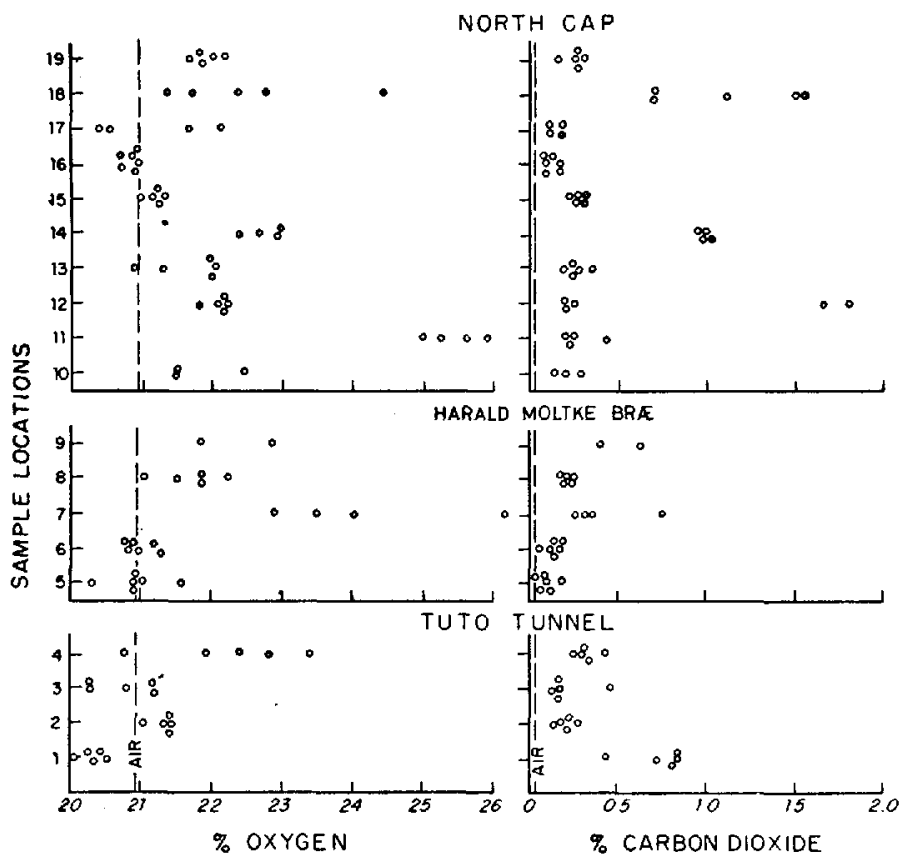

Fig. 5. Oxygen and $\mathrm{CO}_{2}$ concentration in gases from glaciers in the Thule area. Sample numbers correspond to those in Figure 2
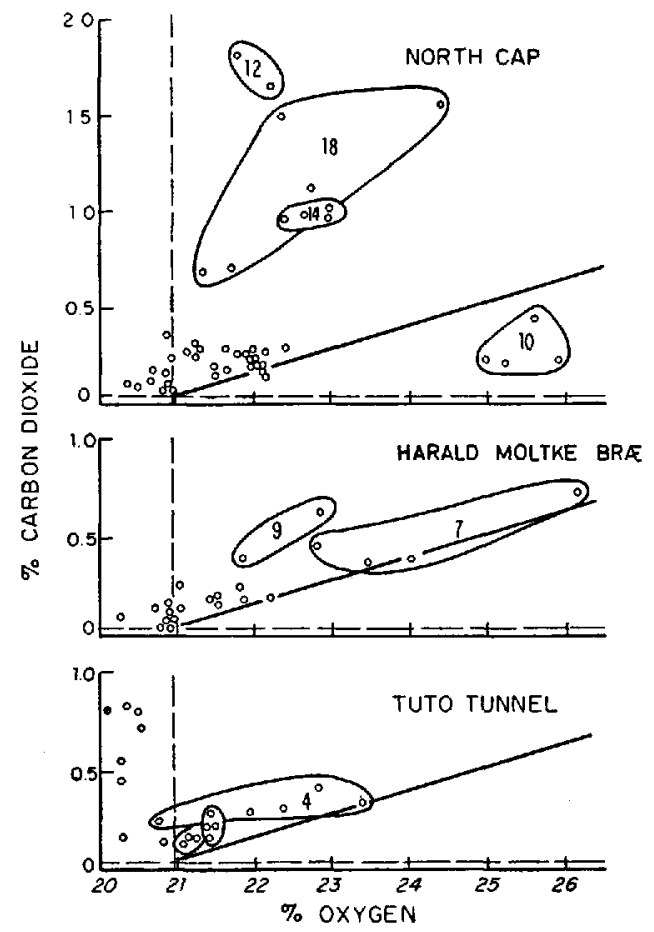

Fig. 6. Oxygen vs. carbon dioxide relation in glacier ice gas. Diagonal lines represent this relation if air is mixed in various proportions with gases frozen out from air-equilibrated water 
The third series of data comes from analysis of individual bubbles in refrozen iceberg cracks. The oxygen concentrations in these bubbles were all high, ranging from 30 to $3^{8}$ per cent (Table I).

Table I. Oxygen Concentration in Single Bubbles of Cragk Fill Ice, Melville Bugt

\begin{tabular}{cccccc} 
& Piece & \multicolumn{4}{c}{ Per cent oxygen } \\
Berg I & a & $38 \cdot 2$ & $3 \mathrm{I} \cdot 6$ & $3 \mathrm{I} \cdot 2$ & \\
& $\mathrm{~b}$ & $34 \cdot 8$ & & & \\
& $\mathrm{c}$ & $3 \mathrm{I} \cdot 6$ & $3 \mathrm{r} \cdot 4$ & $30 \cdot 8$ & $30 \cdot 0$
\end{tabular}

$\begin{array}{llll}\text { Berg } 2 & \text { a } & 3^{1 \cdot 7} & 3^{1} \cdot 6\end{array}$

A fourth series was taken from the clear ice which came floating up from the bottom of various glacier fronts. These clear icebergs were often covered with silt and sand, and they, also, showed a tendency to have high oxygen (Table II).

Table II. Oxygen Congentration in Single Bubbles from Blue Bottom Ige, Melville Bugt

\section{Discuisston}

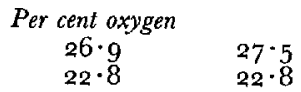

All of our gas samples are apparently different from atmospheric air, and one may therefore inquire what sort of processes may have caused this deviation. There seem to be two rather clear sources of contamination, both involving warming of the ice. One is at the site of ice formation in the firn area; the other is below at the terminus.

If dissolved atmospheric gases in melt water freeze out in the firn and simply add to the entrapped air, one would expect each sample to reflect a simple algebraic mixing-composition of these components, with a consequent enrichment of carbon dioxide, oxygen, and argon relative to nitrogen. A strict relation of this kind has never been found in our samples (Figs. 4 and 5), but one may more or less trace such a dependence in the Thule samples, in the sense that there is a slight correlation between increase in oxygen and increase in carbon dioxide and argon concentration (Figs. 6 and 7).

Considering, however, that in this series there is a general elevation of argon, carbon dioxide, and oxygen, one may assume that freezing of melt water has enriched the air bubbles in these components, and one may hence conclude that the firn was subjected to seasonal melting, something which certainly may take place in this region today.

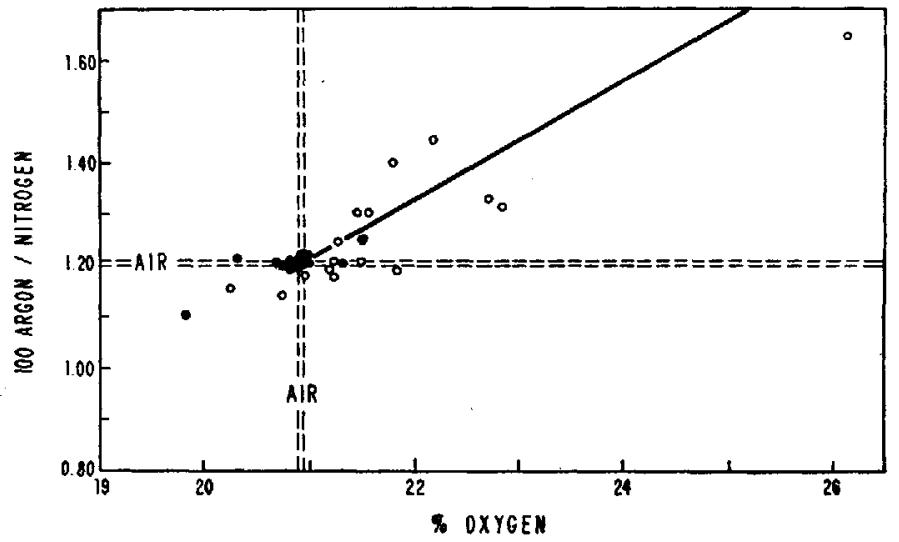

Fig. 7. Argon/nitrogen vs. oxygen relation in iceberg gas. Diagonal line represents the relation if air is mixed in various proportions with gases frozen out from air-equilibrated water 
The opposite of this, so to speak, was seen rather clearly in the earlier Storbreen series, for here oxygen and argon were preferentially lost in the lower regions of the glacier, very likely because of water loss when gas bubbles under pressure melted and expanded during the summer. The carbon dioxide, although higher than in air, showed a similar drop.

It is evident that when melting occurs, both at the site of ice formation and towards the terminus, complex situations arise which seemingly cannot be deciphered. Added to this, there is the possibility that the snow itself, for instance through contact freezing of supercooled fog, may have carried occluded gases when it settled on the ice sheet. This would also increase the relative amount of oxygen, carbon dioxide and argon. All of our radiocarbon samples were significantly lower in the ${ }^{\mathrm{I} 3 \mathrm{C}}$ isotope than is the present-day atmosphere, indicating that the air in the bubbles was contaminated with organic $\mathrm{CO}_{2}$. Evidently the snow could have been contaminated by organic dust which then became oxidized. It is quite clear that analyses must be made of the snow and gases at various sites on the ice sheet before one can settle the problem of the initial contamination of the air.

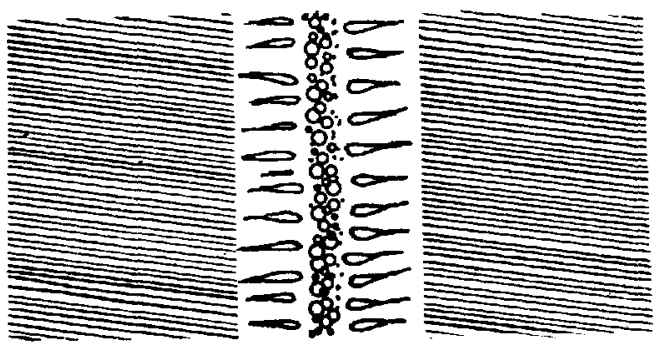

Fig. 8. Typical texture of crackfill ice

Gas bubbles in crackfills and blue ice

Under special conditions the composition of air bubbles in ice lends itself to interpretation of how the ice was formed. The clearest case is that of bubbles in crack fills. It is a common property of almost every iceberg that they have smaller or larger ice-filled cracks often extending as a plane through the entire berg. These cracks are often blue in color and vary greatly in width from a fraction of a centimeter to several decimeters. The ice which fills these cracks frequently presents a bisymmetrical structure (Fig. 8). The outer zone, that is the one in contact with the white glacier ice, is made up of clear ice. Inside this is a zone of elongated bubbles, often of teardrop shape and with a rounded end pointing toward the midsection. The latter is opaque due to a spray of smaller bubbles. The structure is similar to that exhibited by a bisected ice cube from the refrigerator, and the mode of formation is undoubtedly much the same, that is by freezing of the water from the walls inward. Accordingly, when a crack is formed in the glacier ice, it may become filled with melt water. This water freezes rapidly upon contact with the cold ice walls, starting at the water-ice interface and proceeding inward. The gases are forced out of solution and remain as bubbles in the mid-zone. This explanation is supported by considering the bubble composition (Table I), which reveals a very high oxygen concentration, sometimes approaching the concentration of 35 per cent found when air dissolves in water at $0^{\circ} \mathrm{C}$. In other cases, however, the ice which fills the crack has bubbles which are more diffusely distributed. Perhaps snow had compacted in these cracks prior to the inundation, or possibly the original bisymmetrical pattern had changed by redistribution of gas under very high pressures.

Bubbles in blue ice

Common among the bergs and debris coming off the glacier fronts are smaller bergs that are wholly or partly bluish in color and are often covered with silt and gravel. Where the 
blue ice is fused onto regular white glacier ice in the same piece, there is often a sharp transition between them. The blue ice is clear, and has mostly only a few scattered bubbles which may be several centimeters in diameter and are often of irregular shape. Analysis of these gas bubbles revealed that they frequently have an elevated oxygen concentration. (Table II).

One may frequently see that such pieces come floating up from the bottom in front of the glacier wall, and this fact, together with the composition of the gas, suggests the following mode of formation, namely that melt water in the summer time runs down through crevices in the glacier, where it collects over the rock bottom and freezes, expelling the dissolved gas as bubbles which mix with whatever air may have collected under the ice. This would account for the lack of finely dispersed bubbles in this ice, and also for the elevated oxygen concentration.

\section{AGKNOWLEDGEMENTS}

The present investigation was sponsored by the Arctic Institute of North America, with primary funds from the Office of Naval Research (Contract Nonr-I 138(oI), Projects ONR229 and 240). The U.S. Air Force Gambridge Research Genter contributed to the over-all project, and we wish to acknowledge the helicopter assistance rendered us by the U.S. Air Force at Thule Base. The Ministry for Greenland kindly granted permission to carry out the field studies. Appreciation is expressed to these organizations for their assistance and cooperation.

We are much indebted to Professor Hans W:son Ahlmann and Rear Admiral Leo $O$. Colbert, and to the late Professors Carl G. Rossby and H. U. Sverdrup for stimulating discussions of the over-all project. We wish to express our gratitude to Dr. Harold C. Urey for use of his mass spectrometer in the argon/nitrogen determinations.

MS. received 12 fuly 1960

\section{REFERENCES}

I. Scholander, P. F., and others. Studies on the physiology of frozen plants and animals in the Arctic, by P. F. Scholander, W. Flagg, R. J. Hock and L. Irving. Fournal of Cellular and Comparative Physiology, Vol. 42, Suppl. I, I 953 .

2. Hemmingsen, E. Permeation of gases through ice. Tellus, Vol. I 1, No. 3, 1959, p. 355-59.

3. Scholander, P. F., and others. Gases in icebergs, by P. F. Scholander, J. W. Kanwisher and D. C. Nutt. Science, Vol. I 23, No. 3186, I 956, p. 104-05.

4. Shumskiy, P. A. Osnoyy strukturnogo ledovedeniya. Petrografya presnogo l'da kak metod glyatsiologicheskogo issledovaniya. Moscow, Izdatel'stvo Akademii Nauk SSSR, 1955- [French translation: Principes de glaciologic' structurale. La pétrographie de la glace comme méthode d'étude glaciologique. Annales du Centre d'Études et de Documentation Paléontologiques, No. 22, 1957.]

5. Coachman, L. K., and others. Gas enclosures in a temperate glacier, by L. K. Coachman, E. Hemmingsen and P. F. Scholander. Tellus, Vol. 8, No. 4, I956, p. 4I5-23.

6. Coachman, L. K., and others. Gas loss from a temperate glacier, by L. K. Coachman, T. Enns and P. F. Scholander. Tellus, Vol. 10, No. 4, I958, p. 493-95.

7. Coachman, L. K., and others. Gases in glaciers, by L. K. Coachman, E. Hermmingsen, P. F. Scholander, T. Enns and H. de Vries. Science, Vol. I 27, No. 3309 , 1958, p. 1 $288-89$.

8. Nutt, D. C. Recent studies of gases in glacier ice. Polar Notes (Dartmouth College, Hanover, N.H.), No. I, I 959 , p. $57-66$.

9. Scholander, P. F., and Nutt, D. C. Bubble pressure in Greenland icebergs. Journal of Glaciology, Vol. 3, No. 28,1960, p. 67 ז -78 .

I0. Scholander, P. F., and others. Radio-carbon age and oxygen ${ }^{\mathrm{I}}{ }^{\mathrm{B}}$ content of Greenland icebergs, by P. F. Scholander, W. Dansgaard, D. C. Nutt, H. de Vries, L. K. Coachman and E. Hemmingsen. Meddelelser om Gronland, Bd. I65, Nr. I, Ig6r. [In the press.]

11. Scholander, P. F. Analyzer for accurate estimation of respiratory gases in one-half cubic centimeter samples. Journal of Biological Chemistry, Vol. 167, No. 1,1947, p. $235^{-50}$.

I2. Scholander, P. F., and others. Micro gasometric determination of dissolved oxygen and nitrogen, by P. F. Scholander, L. Van Dam, C. L. Claff and J. W. Kanwisher. Biological Bulletin, Vol. I09, No. 2, 1955, p. 328-34.

13. Scholander, P. F., and Evans, H. J. Microanalysis of fractions of a cubic millimeter of gas. Joumal of Biological Chemistry, Vol. I69, No. 2, 1947, p. $55^{\text {I-6o. }}$ 